\title{
OPERATIONAL EFFICIENCY IN HIGHER EDUCATION IN NIGERIA: A SCALE DEVELOPMENT: A CASE STUDY OF COVENANT UNIVERSITY, OTA, OGUN STATE, NIGERIA
}

\author{
KEHINDE, Busola E. ${ }^{1 *}$, OGUNNAIKE, Olaleke O. ${ }^{2}$, IBIDUNNI, Ayodotun $\mathrm{S}^{3}$, ILOGHO, \\ Simon 0. ${ }^{4}$, ADEDUGBA, Adebayo T. ${ }^{5}$, KEHINDE, Segun I. ${ }^{6}$ \\ ${ }^{1}$ Ms., Covenant University, Nigeria busola.kehinde@covenantuniversity.edu.ng \\ ${ }^{2}$ Dr., Covenant University, Nigeria Olaleke.ogunnaike@covenantuniversity.edu.ng \\ ${ }^{3}$ Dr., Covenant University, Nigeria ayodotun.ibidunni@covenantuniversity.edu.ng \\ ${ }^{4}$ Mr., Covenant University, Nigeria simon.ilogho@covenantuniversity.edu.ng \\ ${ }^{5}$ Mr., Covenant University, Nigeria Adebayo.adedugba pgs@stu.cu.edu.ng \\ ${ }^{6}$ Mr., Covenant University, Nigeria segun.kehinde@stu.cu.edu.ng \\ ${ }^{*}$ Corresponding Author
}

\begin{abstract}
This research paper presents a reconceptualization operational efficiency construct within an institution context, specifically, in the Nigerian higher educational Institution-University. The research applied a single case study of Covenant University, Ota, Ogun State, Nigeria. This study used a multi-stage development of scale process where on an online survey. Seven dimensions were identified: teaching, research and publication, recruitment and selection, community service, technology, training and development and effective communication. The study provides evidence of the scale's reliability and validity. The scale proposes a new approach to measure, evaluate operational efficiency within the higher educational institution, and shows the need to go beyond the traditional approach to efficiency.
\end{abstract}

Keywords: Case study research; Nigerian higher educational sector; Operational efficiency; Operational scale development

\section{INTRODUCTION}

Excellence in operations in any business is a critical drive for success in any academic institution. In order to achieve growth and progress, there is a vital need to for the organisation to achieve results in their operations. Operational efficiency can be described the happenings when there exists the proper mixture of people, technology and process so as to improve the effectiveness, productivity and performance of the organization.

Even with the benefits of operational efficiency to all organizations, performance improvements still fails 
because of ineffective communication to the other parts the organization (Kehinde, Ogunnaike, Adegbuyi, \& Ibidunni, 2020). Various studies have addressed the issue of operational efficiency (Ishael \& Nordi, 2017), but few studies have focused on its impact in higher education. The academic environment places so much pressure on top level management to efficiently and effectively react to rapidly dynamic social, technological and conceptual processes so as to produce value for organisational stakeholders and shareholders (Bolboli \& Reiche, 2013).

There exists a major gap in our knowledge of operational efficiency in higher education, and as more research has been done in the service and manufacturing sector but this cannot be applied to the educational sector (Ibidunni, et al., 2018).. For example, within the telecommunication industry, operational efficiency is seen as driven by operational aspects of the human resource department, supply chain department and quality control management, which is a function of public perception and customer satisfaction (Scheraga, 2004). Therefore, this study concentrates on the aspect of institutional performance; the role of process design, the impact of information technology and the people that are involved in this process of operational efficiency.

\section{LITERATURE REVIEW}

Terms such as operational efficiency, efficiency in operations, operational optimization and performance efficiency can be seen in the operational efficiency literatures and thus has been used interchangeably. The debate about the practical use of operational efficiency presents the need for an institution to restructure and project effective approach to the sourcing and deployment resource to achieve set goals (Ibidunni, Ufua, Okorie, \& Kehinde, 2019). It equally highlights the need to identify and eliminate operational wastes that do not add value to the higher educational system (Elbert, 2013). This leads the practicing manager to take decisive steps and actions such as, decrease idleness and waste while still balancing the resources that contributes the greatest to the organization's accomplishment, and also making the best use of the organization's human resource, technology and organisation's processes (Odunga, Nyangweso, \& Nkobe, 2013). Therefore, the higher the operational efficiency of a firm the better its profitability (Baik et al 2011).

Operational efficiency is seen as the combination of technology, process and people with the aim of improving productivity and value in the organisation (Shawk, 2008). It does not just entail reducing cost and increasing profit, it includes diversification, quality maintenance and retaining customers by providing services. UNESCO described it as "the ability to perform well or achieve a desired result or output without any iota of wasting resources, money and time". It is referred to as a systematic management of institution resources to achieve maximum output. Operational efficiency underpins an institutions' strategic goals which helps improve overall performance of the organisation.

While these concluding descriptions of operational efficiency provide some understanding of the term of operational efficiency, they highlighted operational factors in developing technology, people and process. A more all-inclusive understanding of this terminology would define operational efficiency as "the process of applying and combination of people, technology, process, research and publication, communication, community service, training and development and effective teach in a cost effective way which will not in any way reduce the quality of the final output thereby making the higher education gain competitive advantage over all its competitors". This description takes an all-inclusive interpretation of the operational efficiency concept as it does not just reflect an extensive variety of operational efficiency factors, but also studies repercussions on the institution's performance

The enactment and practice of efficiency depends on the underpinning operational philosophy that provides the platform for an all- round practice involving participants in an operational process (Ogunnaike, Bishop, Akinsulire, Kehinde, \& Oreagba 2018).. The practice of operational efficiency adopts the operational tradition that says that event in an operational process is an emergent or dependent on another. It therefore creates an alignment of the manager's decisions and actions with the external environment conditions (Daft, 2009). The Nigeria higher educational sector tends to have embrace these practices to enhance a continuous development and accountability and partnership with relevant stakeholders in a the process of effective educational practice (Varghese, 2004)

\section{METHODOLOGY}

The research adopts a single case study higher institution of learning. The case study possesses the needed operational standards that could support the objective of this the research. The use of case study approach was therefore chosen to project detailed learning on the subject of operational efficiency in the Nigerian higher educational service sector (Asiyai, 2015). 
The use of questionnaire method was adopted for dada collection. This was chosen to effectively gather research data from respondents. After a brief depiction of the research paper, data collection through questionnaire commenced with the gathering of bio-data about the institution, institution's employees base. 150 responses of online survey was retrieved of questionnaire were distributed among the respondents. The study population comprised of academic and senior non-academic staff of Covenant University, Ota Nigeria. These respondents have the experiences and knowledge required to provide the needed data for analysis in this research process. Covenant University is currently the best university in Nigeria under the Times Education ranking (Deutskens, De Jong, de Ruyter, \& Wetzels, 2006)

Primary data sourced with the questionnaire covered items that focused on efficiency measures towards increasing organisational performance. Probing items on the designed questionnaire focused on variables applied in this research. These include the impact of teaching, research and publication, training and development, community service, recruitment and selection, technology and effective communication were also included (Davies \& Francis, 2018).

\section{DATA ANALYSIS}

\section{Item reduction and exploratory factor analysis}

With the aim of validating the operational efficiency scale as well as its arrangement, a chain if exploratory and confirmatory factor analyses was done because it is a technique used in scale development (Bearden, Hardesty and Rose, 2001; Orcan, 2018). The raw data were coded and vetted to discover outliers and to check for defilements of the traditions of multivariate analysis. The first step of the analysis was done with the Statistical Package for Social Sciences (SPSS version 25). SPSS was also used to conduct the initial exploratory factor analysis (EFA). The next stage to approximate the various confirmatory factor analysis (CFA) was tested with LISREL 8.51.

Exploratory factor analysis was done with the aid of principal component analysis as there no prior evidence to show that the dimensions were not related. The KMO sampling adequacy was 0.422 , signifying that factor analysis was acceptable. An iterative procedure was done in order to remove items with low and high cross loadings (Hair, et al 2006).

The last factor analysis had all factors with eigenvalues equals to one that collectively elucidated $48 \%$ of the total variance. A review of the factor loadings proposed that the first factor reflected an institution ability to focus on the operational factors that influences teaching such as the time allotted for classes, the use of smart boards and white boards and a well-integrated library system. The second dimension research and publication dimension (i.e., a institution's ability to develop research and publication desires, and an ability to implement the necessary programmes for conducting research and. The third dimension measured training and development (i.e., a institution ability to train her employees on the use of equipment and how to carry out their respective jobs). The fourth dimension signify community service and the last on the exploratory factor analysis is the technology dimension (i.e. the institution's ability to effectively use technical and systems for carrying out day to day operational activities). These dimensions give a broader conceptualization to the input and output process earlier discussed, which has not been measured in this way. The Cronbach alphas for the all dimensions is shown in Table 4.1

Table: 4.1

\begin{tabular}{|l|l|}
\hline Operational Efficiency Variables & Cronbach Alpha \\
\hline Teaching & 0.637 \\
\hline Research and Publication & 0.504 \\
\hline Training and Development & 0.649 \\
\hline Community Service & 0.784 \\
\hline Recruitment and Selection & 0.844 \\
\hline Technology & 0.627 \\
\hline Effective Communication & 0.735 \\
\hline
\end{tabular}

Source: Field Survey, 2020

The result above shows that three of the scales had a high internal consistency and reliability with the Cronbach alpha values being greater than the minimum acceptable parameter of 0.7 . While the remaining three parameters were slightly below the acceptable parameter. 
Proceedings of ADVED 2020-6th International Conference on Advances in Education 5-6 October 2020

Table 4.2 Result of Construct Validity and Reliability

\begin{tabular}{|c|c|c|c|c|c|c|c|}
\hline & & Loading & $\begin{array}{l}\text { Indicator } \\
\text { Reliability }\end{array}$ & $\begin{array}{l}\text { Error } \\
\text { Variance }\end{array}$ & $\begin{array}{l}\text { Composite } \\
\text { Reliability }\end{array}$ & Average & $\begin{array}{l}\text { No. of } \\
\text { Indicators }\end{array}$ \\
\hline & Variables & $>0.7$ & & $<0.5$ & $>0.7$ & $>0.5$ & \\
\hline \multirow{6}{*}{ Teaching } & $\mathrm{T} 1$ & 0.825 & 0.6806 & 0.3194 & & & \\
\hline & T2 & 0.727 & 0.5285 & 0.4715 & & & \\
\hline & T3 & 0.795 & 0.6320 & 0.3680 & & & \\
\hline & T4 & 0.806 & 0.6496 & 0.3504 & & & \\
\hline & T5 & 0.840 & 0.7056 & 0.2944 & & & \\
\hline & T6 & 0.822 & 0.6757 & 0.3243 & 0.9159 & 0.6453 & 6 \\
\hline \multirow{6}{*}{$\begin{array}{l}\text { Research and } \\
\text { Publication }\end{array}$} & RP7 & 0.7920 & 0.6273 & 0.3727 & & & \\
\hline & RP8 & 0.7930 & 0.6288 & 0.3712 & & & \\
\hline & RP9 & 0.7340 & 0.5388 & 0.4612 & & & \\
\hline & RP10 & 0.9040 & 0.8172 & 0.1828 & & & \\
\hline & RP11 & 0.8440 & 0.7123 & 0.2877 & & & \\
\hline & RP12 & 0.7620 & 0.5808 & 0.4194 & 0.9176 & 0.6508 & 6 \\
\hline \multirow{4}{*}{$\begin{array}{l}\text { Training and } \\
\text { Development }\end{array}$} & TD13 & 0.7250 & 0.5256 & 0.4744 & & & \\
\hline & TD14 & 0.8380 & 0.7022 & 0.2978 & & & \\
\hline & TD15 & 0.7630 & 0.5822 & 0.4178 & & & \\
\hline & TD16 & 0.8710 & 0.7586 & 0.2414 & 0.8772 & 0.6422 & 4 \\
\hline \multirow{5}{*}{$\begin{array}{l}\text { Community } \\
\text { Service }\end{array}$} & CS17 & 0.9240 & 0.8538 & 0.1462 & & & \\
\hline & CS18 & 0.8180 & 0.6691 & 0.3309 & & & \\
\hline & CS19 & 0.8440 & 0.7123 & 0.2877 & & & \\
\hline & CS20 & 0.8210 & 0.6740 & 0.3260 & & & \\
\hline & CS21 & 0.8650 & 0.7482 & 0.2518 & 0.9315 & 0.7315 & 5 \\
\hline \multirow{2}{*}{$\begin{array}{l}\text { Recruitment } \\
\text { and Selection }\end{array}$} & ES22 & 0.8600 & 0.7396 & 0.2604 & & & \\
\hline & ES23 & 0.8090 & 0.6545 & 0.3455 & 0.8213 & 0.6970 & 2 \\
\hline \multirow[t]{4}{*}{ Technology } & TC24 & 0.8730 & 0.7621 & 0.2379 & & & \\
\hline & TC25 & 0.7920 & 0.6273 & 0.3727 & & & \\
\hline & TC26 & 0.8880 & 0.7885 & 0.2115 & & & \\
\hline & TC27 & 0.7990 & 0.6384 & 0.3616 & 0.9047 & 0.7047 & 4 \\
\hline \multirow{3}{*}{$\begin{array}{l}\text { Effective } \\
\text { Communication }\end{array}$} & EC28 & 0.7885 & 0.2115 & 0.7885 & & & \\
\hline & EC29 & 0.6480 & 0.3520 & 0.6480 & & & \\
\hline & EC30 & 0.6022 & 0.3978 & 0.6022 & 0.8638 & 0.6796 & 3 \\
\hline
\end{tabular}

All loading are significant at $p<0.0001$

Source: Field Survey, 2020 


\subsection{Reliability and Validity assessment}

The factor loadings were bought from the EFA (Table 4.4) in which all the items recommended must be valid and reliable so far as they have they are equal or above 0.7 (Hair et al, 1991). The error variance was also recommended to be acceptable if the values are less than 0.5 .

According to Fornell and Larcker (1981), the composite reliability which should access the internal consistency is acceptable if the values are equal or greater than 0.7 . From the above table, each of this items have an internal consistency greater than 0.7 . While the average recommended value must be equal or greater than 0.5 . Each of the item in the construct of validity and reliability are valid and reliable because they pass the recommended value test.

\section{DISCUSSION AND CONCLUSIONS}

The current study highlights useful findings on the subject of operational efficiency in the Nigerian higher educational sector. The research finding shows that practice efficiency adds to teaching and development operational efficiency in different significant ways. For instance, training and development capability dimension also reflects an institution's ability to develop several methods of employee training and development through innovative programs, faculty support, conferences and journal supports programs.

This aligns with the findings of Omotayo, Zikhali, and Jackreece, (2019), who emphasise on the need for training, especially in the Nigerian higher educational sector. They explain that training, both for teaching, research and non- academic staff, can impact positively on the overall efficiency of the sector. They also found out that effective training program can enhance the interest of participating staff in the pursuit of set objectives.

First, the study reacts to recent calls to evaluate the dimensions through which higher academic institutions attain more efficiency since all indications proposes the idea of teaching which advanced based on concepts and models developed in service industries may not be the similar in higher institutions. For example, quite a number of researchers were of the opinion that there exists other factors which are not operational in the higher institution (e.g., management, students, facilities, laboratories, departments, classes). Researchers (e.g., Abdalmenem, Abu-Naser, Al Shobaki, and Abu Amuna, 2019) recognise the importance of e-learning and use of sophisticated resources to provide higher educational learning efficiently, reaching out to a wider scope of recipients. They suggest the need for higher education providers to consider the provision of adequate resources for enhancing higher educational learning. This finding corroborates the study of Okolie, Igwe, and Elom, (2019), who highlights the need for sufficient funding and attention to the provision of the needed support for efficient learning across boundaries.

Furthermore, the current study approaches the fieldwork with the aim to test higher educational institution's measures on a multidimensional scale for operational efficiency. In the initial stage of scale development, several understandings were gained into the array of dimensions of operational efficiency in higher education context, which formed the foundation for the other scale development phases and modifications that used an online based survey $(n=150)$. The procedure led to the six-dimensional (teaching, training and development, recruitment and selection, technology, community service and effective communication), ten-item operational efficiency scale that reveals the exclusive features of higher educational institutions central activities and responsibilities. Whilst their research focused on the same sector and the adopted approach are the same, Oyelaran-Oyeyinka and Adebowale (2017), suggest the need for collaboration and noted that the size of the higher institution of learning determines the extent to which such collaborative effort can yield the needed operational efficiency.

The study further gives a more pronounced and contextually gainful conceptualisation of operational efficiency capability than what had been offered before. The teaching- focused operational efficiency capability dimensions shows an institution capability to provide the students with adequate knowledge as well at insights on the specific areas of study. This conceptualization is wider than prior suggested operational efficiency dimensions and measures.

The recruitment and selection capability dimension is also very important in the academic institution, this is because, the right set of employees recruited in the institution goes a long way toward providing the institution with the achievement of organisational goals and objectives.

The technological focused operational efficiency dimension is vital in the institution. The use of visual aids and audio aids would help improve effective communication across all levels, whether teacher-student or management-employees. Visual aids such as projectors, laptops, smart boards, white boards are needed to 
aid effective learning approach in the higher education (Abdalmenem, Abu-Naser, Al Shobaki, and Abu Amuna, 2019).

The last dimension is the communication focused operational efficiency; effective communication entails the transfer of information, ideas, and opinions through a medium from the sender to the receiver where there is room for feedback. This is needed in an academic institution because it provides the avenue for a student based learning approach. Communication also helps in providing the academic community with the rules and policies for the day to day academic activities.

It was thus evident from the in-depth online survey, the ability of an institution to implement these operational efficiency dimensions is looked at as a method to stay ahead to gain competitive advantage. Thus, the interactive way in which the institution's professionals suggest that the impact of employees on operational dimensions goes a long way towards achieving the organizational goals and objectives.

The results and findings from the current research agrees with the proposition that due to the distinct characteristics of educational institutions, dimensions developed in other settings may not capture higher educational institutions operational efficiency. For example, a number of item reductions were done in the exploratory factor analysis stage, these items were found to be associated with the teaching capability dimensions (Table 4.4), but these items were left out during the confirmatory factor analysis stage of the scale development phases.

\subsection{Managerial Implications}

Generally, the pattern of findings shows the distinct operational efficiency measures of educational institutions. The operational efficiency measures have thirty-one items that measure six dimensions and, thus making it an efficient method to assess an institution's operational efficiency capability. The dimension provides senior management with a useful understanding on how to improve operational efficiency in the institution. For example, the evaluation of an institution's operational efficiency should help the senior management in evaluating the dimensions and areas that need to be addressed, and this makes them to respond to the dynamic challenges imposed by the various operational efficiency dimensions that need to be worked upon. Also identifying the recruitment and selection dimensions that best enhance the productivity of the institution in order to engender effective contribution towards achievement of organization's goals and objectives. Furthermore, evaluating the community service and teaching dimensions would assist the institution to build a strong relationship with her immediate environment.

\section{ACKNOWLEDGMENT}

The authors of this article acknowledges Covenant University for full sponsorship of this research.

\section{REFERENCE LIST}

Abdalmenem, S. A., Abu-Naser, S. S., Al Shobaki, M. J., \& Abu Amuna, Y. M. (2019). Increasing the Efficiency of Palestinian University Performance through the Implementation of E-Learning Strategies.

Asiyai, R. I. (2015). Improving Quality Higher Education in Nigeria: The Roles of Stakeholders. International Journal of higher education, 4(1), 61-70.

Baik, B., Chae, J., Choi, S., \& Farber, D. (2011). Changes in operational efficiency and firm performance: A frontier analysis approach. Contemporary Accounting Research, 20(10), 1-32.

Bolboli, S., \& Reiche, M. (2013). The model for Sustainable business excellence: Implementation and the roadmap. Total Quality Management Journal, 1754-2731

Daft, R. L. (2009). Organization Theory and Design. Mason: South-Western College Publication.

Davies, P., \& Francis, P. (2018). Doing criminological research. SAGE Publications Limited.

Elbert, M. (2013) Lean Production for the Small Company, London, CRC Press.

Eze, S. C., Awa, H. O., Okoye, J. C., Emecheta, B. C., \& Anazodo, R. O. (2013).Determinant factors of information communication technology (ICT) adoption by government-owned universities in Nigeria: A qualitative approach. Journal of Enterprise Information Management, 26(4), 427-443. 
Ferreira, A., \& Otley, D. (2005). Otley, D., \& Ferreira, A. (2005). The Design and use of management control systems: An extended framework for analysis. Social Science Research Network Working Paper, 682984

Hatzakis,E.D., Nair, S.K. and Pinedo, M.L. (2010). Operations in financial services-An overview. Production and Operations Management. 19(6). 633-664

Ibidunni, A. S., Kehinde, O. J., Ibidunni, O. M., Olokundun, A. M., Falola, H. O., Salau, O. P., .. and Peter, F. (2018). Data on the relationships between financing strategies, entrepreneurial competencies and business growth of technology-based SMEs in Nigeria. Data in brief, 18, 988-991.

Ibidunni, A. S., Ufua, D. E., Okorie, U. E., and Kehinde, B. E. (2019). Labour productivity in agricultural sector of Sub-Sahara Africa (2010-2017): A data envelopment and panel regression approach. African Journal of Economic and Management Studies, 11(2), 207-232.

Kehinde, B.E., Ogunnaike, O.O., Adegbuyi, O.A., and Ibidunni, A.S. (2020). Analysis of inventory management practices for optimal economic performance using $\mathrm{ABC}$ and $\mathrm{EOQ}$ models. International Journal of Management. 11(7), 835-848

Mutahi, N. (2015). Effect of human resource management practices on performance of public universities in Kenya. International Journal of Economics, Commerce and Management, 3(10), 696-736.

Nadler, J. T., Weston, R., \& Voyles, E. C. (2015). Stuck in the middle: the use and interpretation of midpoints in items on questionnaires. The Journal of general psychology, 142(2), 71-89.

Odunga, R. M., Nyangweso, P. M., \& Nkobe, D. K. (2013). Liquidity, capital adequacy and operating efficiency of commercial banks in Kenya. Research Journal of Finance and Accountung, 4(8), 76-80.

Ogunnaike, O.O., Bishop, S., Akinsulire, H., Kehinde, B. E. and Oreagba, O. T. (2018). Education for Sale: Marcov chanin analysis of phyical qualities and engineering students switching behaviour. International Journal of Mechanical Engineering and Technology. 9(12), 230-239

Okolie, U. C., Igwe, P. A., \& Elom, E. N. (2019). Improving graduate outcomes for technical colleges in Nigeria. Australian Journal of Career Development, 28(1), 21-30.

Olokundun, A. M., Ogbari, M. E., OBI, J. N., \& Ufua, D. E. (2019). Business incubation and student idea validation: a focus on Nigerian universities. Journal of Entrepreneurship Education, 22(1), 1-6.

Omotayo, O. A., Zikhali, P. T., \& Jackreece, O. P. (2019). Measuring behaviour and attitude of workers to staff development and training the University of Port Harcourt, Nigeria. Gender and Behaviour, 17(2), 13268-13274.

Orcan, F. (2018). Exploratory and confirmatory factor analysis: Which one to use first? Journal of Measurement and Evaluation in Education and Psychology. 9(4), 414-421 Oyelaran-Oyeyinka, B., \& Adebowale, B. A. (2017). University-industry collaboration as a determinant of innovation in Nigeria. Institutions and Economies, 21-46.

Scheraga, C. A. (2004). The relationship between operational efficiency and customer service. A global study of thirty eight large international airlines.

Shawk. (2008). Operational Efficiency a Brand Point Management Perspective . Retrieved 10 2018, 25, from http://www.schawk.com.

Shehadeh, R. M., Maqableh, M., Al-Zoub, M. O., Akhorshaideh, A. O., \& Al-Shami, M. K. (2016). Review the operational excellence factors of service firms: A literature review. European Journal of Business and Management, 8(3).

Simon, H. (1976). A study of decision-making process in administrative organiation. . New York: Free Press.

Varghese, N. V. (2004). Private higher education in Africa. International Institute for Educational Planning (IIEP). UNESCO, Geneva. 